vaccine Am I Infect Control 1989:17:126-129.

3. Bryan JP, Sjogren M, Iqbal M, Khattak AR, Nabi S, Ahmed A, et al. Comparative trial of low-dose, intradermal, recombinant- and plasmabased hepatitis B vaccines. J Infect Dis 1990;162:789-793.

4. Heijtink RA, Breukers AA, den Hartigh G, Schepman RW, Schmitz I, Schalm SW, et al. Low-dose intradermal vaccination against hepatitis $B$ in mentally retarded patients. Vaccine 1988;6:59-61.

5. McMaster KR III, Roper JK, Carter JB. Intradermal hepatitis B vaccination in a 300-bed primary care hospital: experience with a recombinant vaccine in a four-dose schedule. Am I Infect Control 1993;21:283-288.

6. Parish DC, Muecke HW, Joiner TA, Pope WT, Halder SC. Immunogenicity of low-dose intradermal recombinant DNA hepatitis B vaccine. Southern Medical Journal 1991;84:426-430.

7. Wistrom J, Settergren B, Gustafsson A, Juto P, Norrby RS. Intradermal versus intramuscular hepatitis B vaccination. JAMA 1990;264:181-182.

8. Redfield RR, Innis BL, Scott RM, Cannon HG, Bancroft WH. Clinical evaluation of low-dose intradermally administered hepatitis $B$ virus vaccine: a cost strategy. JAMA 1985;254:3203-3206.

9. Prasetya E, Linggadjaja W, Syambali R, Kusumo S, Dharmesetyawan DF, Rahardja U. Intradermal vaccination against hepatitis B in Immanuel Hospital personnel-a preliminary report. Ann Academic Medicine 1986;15:153-157.

10. Halsey NA, Reppert EJ, Margolis HS, Francis DP, Fields HA. Intradermal hepatitis $\mathrm{B}$ vaccination in an abbreviated schedule. Vaccine 1986;4:228-232.

11. Wahl M, Hermodsson S. Intradermal, subcutaneous or intramuscular administration of hepatitis $B$ vaccine: side effects and antibody response Scandinavian Journal of Infectious Diseases 1987;19:617-621.
12. Gonzalez ML, Usandizaga M, Alomar P, Salva F, Martin F, Erroz MJ, et al. Intradermal and intramuscular route for vaccination against hepatitis B. Vaccine 1990;8:402-404.

13. Bryan JP, Sjogren MH, Perine PL, Legters LJ. Low-dose intradermal and intramuscular vaccination against hepatitis B. Clin Infect Dis 1991;14:697-707.

14. Hadler SC, Francis DP, Maynard JE, Thompson SE, Judson FN, Echenberg DF, et al. Long-term immunogenicity and efficacy of hepatitis B vaccine in homosexual men. $N$ Engl $J$ Med 1986;315: 209-214.

15. Barnes GP, Hanacik LJ. Hepatitis B Vaccine: persistence of antibody following immunization. Infect Control Hosp Epidemiol 1988;9:147-150.

16. McKinney WP, Horowitz M, Battiola R, Russler S. Duration of response to intramuscular versus low-dose intradermal hepatitis $B$ booster vaccination. ICAAC. Houston, TX; September 1989;17:131. Abstract 181.

17. West DJ. Clinical experience with hepatitis B vaccine. Am J Infect Control 1989;17:172-180.

18. Centers for Disease Control. Update on hepatitis B prevention. $M M W R$ 1987;36:353-366

19. Szmuness W, Stevens CE, Harley EJ. Hepatitis B vaccine in medical staff of hemodialysis units: efficacy and subtype cross-protection. $N$ Engl J Med 1982;307:1481-1486.

20. Szmuness W, Stevens CE, Zang EA, Harley EJ, Kellner A. A controlled clinical trial of the efficacy of the hepatitis B vaccine (Heptovax B): a final report. Hepatology 1981;1:377-385.

21. Krugman S, Davidson M. Hepatitis B vaccine: prospects for duration of immunity. Yale Journal of Biological Medicine 1987;60:333-338.

\title{
Bacterial Contamination of Tube Feedings
}

\section{Gina Pugliese, RN, MS \\ Martin S. Favero, PhD}

Mathus-Vliegen and colleagues from the Department of Gastroenterology and Hepatology, the Academic Medical Center, University of Amsterdam, The Netherlands, conducted a study to investigate the microbial contamination rate of $1-\mathrm{L}$ feeding bottles and newly designed administration sets over hanging times of 24 hours in the ICU. The investigation was a prospective observational cohort study of patients admitted to the ICU of a university hospital. The subjects included all consecutive patients fed via a nasojejunal tube for at least 4 days. Cultures were performed of feeding bottles, administration sets, and gastric and tracheobronchial aspirates at days $0,1,2,4$, and 7 .
Four percent of feeding bottles and $74 \%$ of infusion sets contained $>100$ colony-forming units (CFU) $/ \mathrm{mL}$. Gastric and bronchial aspirates were positive in $90 \%$ and $92 \%$, respectively. Bacterial counts of feeding bottles were $10^{2}$ to $10^{5} \mathrm{CFU} / \mathrm{mL}$. The main bacteria isolated included Enterobacter cloacae, Klebsiella oxytoca, and enterococci. One third of all bacteria grown from cultures obtained from feeding bottles, administration sets, stomachs, and lungs belonged to the Enterobacteriaceae family, which was responsible for the nosocomial infections in the ICU.

None of the 1-L feeding bottles with a hanging time of 19 to 24 hours were contaminated. Only bottles that had to be exchanged because of need for a faster rate of infusion proved to be contaminated, apparently without clinical consequences. With time and the increasing severity of disease, the administration sets became contaminated at an increasingly faster rate and with higher bacterial counts, mainly through retrograde growth of endogenous bacteria. The final step of bottle contamination might have been the bacterial transfer by nurses' hands.

The authors concluded that, despite an almost ideal design of the enteral-nutrition delivery system, there was a $4 \%$ contamination rate of initially sterile feedings with clinically relevant bacteria. The fact that only manipulated systems showed bacterial growth are of concern.

FROM: Mathus-Vliegen LM, Binnekade JM, de Haan RJ. Bacterial contamination of ready-to-use 1-L feeding bottles and administration sets in severely compromised intensive care patients. Crit Care Med 2000;28:67-73. 